\section{Inhibition of Candida species via Proteosome Inhibitor MG-262 (ZL $\left.\mathrm{Z}_{3} \mathrm{~B}\right)$}

\section{Abstract}

Backround: Candida species take the fourth place among the microorganisms which cause hospital infections. New therapeutic agents are needed because of rapidly increasing resistance rates. Boric acid preparations are preferred in local treatment especially in resistant cases while azole formulations are the first choice in oral treatment. The only boric acid analog that was approved by FDA (Food and Drug Administration) for systemic use is Bortezomib (Velcade). Bortezomib is a proteasome inhibitor and proteasome inhibitors cause apoptosis of eukaryotic cells. Although the yeast also has a well preserved 205 proteasome region, the studies on the effects of proteasome inhibitors on the yeast are limited. In this study, the effects of the one of the most potent proteasome inhibitor, MG-262, on Candida spp. were investigated.

Methods: C. albicans ATCC 90028, C. krusei ATCC 6258 and C. glabrata (clinical strain) strains were used in our study. Antifungal susceptibilities of the strains against MG-262 and effects of MG-262 on oxidative metabolism, proteasome activity and apoptosis as well as virulence factors such as hyphal transformation, pseudohypha, germ tube and biofilm formation were investigated. CLSI (Clinical and Laboratory Standards Institute) guidelines were used for antifungal susceptibility tests. The effect on hypha and pseudohypha formation and germ tube were determined with conventional tests. Biofilm formation was detected according to the microplate method. Oxidative metabolism experiments, proteosome activity and apoptosis tests were performed with Alamarblue dye, fluorogenic peptides and DNA ladder assays, respectively.

Findings: MG-262 exhibited minimum inhibitory activity at $25 \mu \mathrm{g} / \mathrm{ml}$ concentration for C. albicans ATCC 90028 and at $50 \mu \mathrm{g} / \mathrm{ml}$ concentration for C. krusei ATCC 6258 and $C$. glabrata. Minimum fungicidal concentrations for all species were $50 \mu \mathrm{g} / \mathrm{ml}$. Hypha, pseudohypha, germ tube and biofilm formation, proteosome activity and oxidative metabolism were all inhibited at $50 \mu \mathrm{g} / \mathrm{ml}$ and higher concentrations. The apoptosis was detected at $200 \mu \mathrm{g} / \mathrm{ml}$.

Conclusion: MG-262 caused apoptosis by inhibiting oxidative metabolism and showed fungicidal activity. It also inhibited the virulence factors such as hypha, pseudohypha germ tube and biofilm formation. Inhibition of proteasome is promising in terms of discovery of a new generation antifungal agent.

Keywords: Apoptosis; Candida spp; Proteazom

\section{Uzunoglu E*, Karaarslan A, Duygu O, Esin A and Murat $O$}

Department of Medical Microbiology, Giresun University, Giresun, Turkey

\section{*Corresponding author: Uzunoglu E \\ ” emeluzunoglu@yahoo.com, emel.uzunoglu75@gmail.com}

Department of Medical Microbiology, Giresun University, Giresun, Turkey.

Tel: +90 5057785529

Citation: Uzunoglu E, Karaarslan

A, Duygu O, Esin A, Murat O (2017) Inhibition of Candida species via Proteosome Inhibitor MG-262 (ZL3B). Arch Clin Microbiol. Vol. 8 No. 4:49

\section{Introduction}

Candida species are a leading causes of the hospital related bloodstream infections with high morbidity and mortality. They cause serious systemic diseases especially when the normal bacterial flora is supressed by widespread use of broad spectrum antimicrobials. Increasing number of solid organ and bone marrow transplantations, invasive procedures and implantable biomaterials are also other predisposing factors [1-3].

Oral azole drugs are the first choice in the treatment of 
candidiasis [4]. Boric acid is one of the local treatment alternatives in resistant cases [5]. Fungicidal effect of boric acid is attributed to the blockage in the oxidative metabolism according to some authors [6]. However, there also are some boric acid analogs which effect as proteasome inhibitor and they can be local treatment alternatives. Nevertheless, the data about the use of proteasome inhibitors for therapeutic purposes on Candida species is limited. Bortezomib (Velcade), originally codenamed PS-341 (pyrazy carbonyl-Phe-Leu-boronate), is the only boric acid analogue proteasome inhibitor, which has received Food and Drug Administration (FDA) approval and is currently used parenterally [7].

Proteasomes are the major non-lysosomal protease structures found in eukaryotic cells. It provides degradation of the misconfigured and ubiquitin labelled proteins. Ubiquitinproteasome enzymatic pathway is located in the cytoplasm and is responsible for the degradation of the abnormal proteins [8]. Ubiquitin mediated degradation of regulatory proteins plays an important role in the control of metabolic processes such as cell cycle progression, signal transmission, transcriptional regulation and apoptosis. Studies on ubiquitin-proteasome system of mammalian cells and yeast species are currently ongoing to solve the complex relationship of this system with the apoptosis pathway [9].

MG-262, originally codenamed ( $\left.\mathrm{ZL}_{3} \mathrm{~B}\right)$ Z-Leu-Leu-Leu-B $(\mathrm{OH})_{2^{\prime}}$ is one of the most potent compound among boric acid analog proteasome inhibitors. It selectively and reversibly inhibits the chymotryptic activity of the proteasome which has a critical role in cell viability and proliferation [10].

In this study, the susceptibility of the active ingredient MG-262 on Candida species was detected and then possible antifungal mechanisms (oxidative metabolism inhibition, apoptosis) and the effects on some virulence factors (hyphal growth, inhibition of cell viability in biofilm condition) were analysed in vitro.

\section{Methods}

\section{Candida strains}

Standard strains; C. albicans ATCC 90028, C. krusei ATCC 6258 and a clinical isolate; $C$. glabrata strain were included. C. glabrata was identified via the standard methods, such as chlamydospore production, germ tube assays, micro-morphology studies in cornmeal-Tween 80 agar and biochemical tests using the commercial system ID32C (bioMérieux Marcy l'Etoile, France). Antifungal susceptibility tests were performed according to the Clinical and Laboratory Standards Institute (CLSI) M27-A3 document and interpreted in accordance with the CLSI M27-S4 suplement $[11,12]$. All fungal isolates were stored at $-80^{\circ} \mathrm{C}$ in the Brain Heart Infusion Broth (Sigma Chemical Co, USA) with $20 \%$ glycerol (Sigma Chemical Co, USA) and $0.2 \%$ agar (Oxoid, UK) suspensions. Before testing, each isolate was cultured on Sabouraud Dextrose Agar (SDA) (Oxoid, UK) to ensure viability.

\section{Stock solutions}

MG-262 (Cat\# I-120) was purchased from Boston Biochemical Inc. (Cambridge, USA) in $1 \mathrm{mg}$ packages. The chemical compound was dissolved in DMSO (Sigma Chemical Co, USA) in order to set serial dilutions. Each of the samples was diluted in RPMI 1640 medium (Sigma Chemical Co, USA) to obtain final concentrations from $0.03 \mu \mathrm{g} / \mathrm{mL}$ to $200 \mu \mathrm{g} / \mathrm{mL}$. Amphoterisin B (Sigma Chemical Co, USA) and Fluconazole (Ibrahim Ethem Ilaç A.S, Istanbul, Turkey) were used as control antimicrobials. Stock solutions of fluconazole and amphotericin B were prepared in distilled water and DMSO, respectively. Stock solutions of the antifungal agents (at 100 times higher concentration) were then diluted with RPMI 1640 medium buffered to $\mathrm{pH} 7.0$ with 0.165 M MOPS (Sigma Chemical Co, USA). The final concentration ranges were 0.03 to $16 \mu \mathrm{g} / \mathrm{ml}$ for amphotericin B and 0.125 to $64 \mu \mathrm{g} / \mathrm{ml}$ for fluconazole. They were frozen in aliquots at $-80^{\circ} \mathrm{C}$ until use [11].

\section{Antifungal susceptibility tests}

Antifungal susceptibility tests of chemicals were performed according to CLSI M27-A3 guidelines by broth microdilution method. As it is defined in the document; round-bottom trays containing RPMI 1640 broth with $0.2 \%$ glucose (Sigma Chemical Co, USA) were incubated at $35^{\circ} \mathrm{C}$ for 48 hours with an $100 \mu \mathrm{l}$ inoculation of $0.5 \times 10^{3}$ and $2.5 \times 10^{3}$ blastoconidia/ml (C. albicans ATCC 90028, C. krusei ATCC 6258, C. glabrata) and $100 \mu \mathrm{L}$ aliquots from each concentration of test substances. After 24 hours of incubation Minimum Inhibitory Concentration (MIC) values were determined visually as the lowest concentration of drug that caused complete inhibition of growth relative to that of the growth control. To obtain the Minimum Fungicidal Concentration (MFC), $100 \mu \mathrm{l}$ of each serial dilution was taken and spread on SDA. Plates were incubated at $35^{\circ} \mathrm{C}$ for 48 hours. The MFC was defined as the lowest drug concentration that yielded $\leq 1$ colony on the agar plate. Results were demonstrated by the absence of colonies on the agar plates. Five per cent aqueous DMSO was negative control $[11,13]$.

\section{Germ tube test}

Germ tube formation was monitored microscopically according to the conventional germ tube test protocol [14]. C. albicans ATCC 90028 strain was placed in human serum-containing media $(10 \% \mathrm{v} / \mathrm{v})$ with or without chemical compounds $(25 \mu \mathrm{g} / \mathrm{ml}, 50 \mu \mathrm{g} /$ $\mathrm{ml}, 100 \mu \mathrm{g} / \mathrm{ml}$ and $200 \mu \mathrm{g} / \mathrm{ml}$ ), and incubated at $37^{\circ} \mathrm{C}$ for 3 hours. The samples were visuliazed with $400 \mathrm{X}$ magnification via an optical microscope (Nikon Eclipse Ci, Japan). MG-262 untreated cells were used as control.

\section{Corn meal agar tests}

Hyphal transformation and pseudohypha production of $C$. albicans ATCC 90028 strain and pseudohypha production of $C$. krusei ATCC 6258 strain were determined via Cornmeal Agar (Oxoid, UK) with 10\% Tween 80 (Oxoid, UK). Before and after incubation with MG-262 for 3 hours, Corn Meal Agar was cut deeply in the form of horizontal furrow with a loopful of suspension colonies and a flamed sterile coverslip was placed over the line of inoculum [14]. After the incubation at $22^{\circ} \mathrm{C}$ the results were observed both at 24 and 48 hours and documented with $400 \mathrm{X}$ magnification under an optical microscope (Nikon Eclipse Ci, Japan). MG-262 untreated cells were used as control. 


\section{Oxidative metabolism experiments}

In our study, Candida strains were exposed to Alamar Blue stain in order to determine the effect of MG-262 on the oxidative metabolism with the method described by Seta et al. with slight modifications [6]. The Alamar Blue system is composed of an oxidation-reduction indicator, which fluoresces and turns from blue to pink secondary to oxidative metabolism and cell growth. The active ingredient of the dye is resazurin which is cell permeable, nonfluorescent and blue in color. Upon entering cells, resazurin is reduced to resorufin, which produces very bright pink fluorescence viable cells continuously convert resazurin to resorufin [15]. In order to determine the effect of chemical compound on oxidative metabolism, $45 \mu$ samples of each strain $\left(1 \times 10^{3} \mathrm{CFU} / \mathrm{ml}\right)$ were exposed to $45 \mu \mathrm{l}$ of serial dilutions $(25 \mu \mathrm{g} /$ $\mathrm{ml}, 50 \mu \mathrm{g} / \mathrm{ml}, 100 \mu \mathrm{g} / \mathrm{ml}$ and $200 \mu \mathrm{g} / \mathrm{ml}$ ) of MG-262 and stained with $10 \mu$ AlamarBlue (Invitrogen, USA) dye. MG-262 untreated cells with alamarblue were used as positive control. The cells were incubated with MG-62 for 1 hour and washed gently. They were also observed for 24 hour in order to detect the colour change. After 24 hours the plate was read at $570 \mathrm{~nm}$ using a microtiter plate reader (Multiskan Ascent, Labsystems, Helsinki, Finland).

\section{Biofilm assays}

The effect of MG-262 on the cell viability in a biofilm condition were evaluated according to the microplate method described by Evensen and Braun with some modifications [16]. Briefly, 1 $\times 10^{6} \mathrm{cell} / \mathrm{ml}$ of the samples were diluted in $100 \mu \mathrm{l}$ Phosphate Buffered Saline (PBS, 0,05 M, pH: 7.2) (Oxoid, UK), inoculated in a 96 well plate and incubated at $37^{\circ} \mathrm{C}$, in a $75 \mathrm{rpm}$ shaker incubator (HVD, Austria). At the end of 48 hours, plates were washed with PBS and the wells filled with $50 \mu \mathrm{l}$ serial dilutions of MG-262 at the concentrations $25-200 \mu \mathrm{g} / \mathrm{ml}$ and $100 \mu \mathrm{l}$ Saboraud Dextrose Broth (Oxoid, UK). After 48 hours of incubation, the medium was removed and the wells were washed with PBS buffer. The plate was stained with $0.4 \%$ crystal violet (Oxoid, UK) for 15 minutes and the wells were air-dried. The crystal violet in each well was solubilized by $200 \mu \mathrm{l}$ of $95 \%$ ethanol. The plate was read at 595 $\mathrm{nm}$ using a (Multiskan Ascent, Labsystems, Helsinki, Finland). MG-262 untreated cells were used as positive control.

\section{Proteasome activity}

Proteasome activity tests were performed according to the method described by Evensen and Braun [16]. In brief, $1 \times 10^{6}$ cell $/ \mathrm{ml}$ of yeast cells were suspended in $100 \mu \mathrm{PBS}$ and kept in 96 well microtiter plate with various concentrations $(200 \mu \mathrm{g} / \mathrm{ml}$, $100 \mu \mathrm{g} / \mathrm{ml}, 50 \mu \mathrm{g} / \mathrm{ml}, 25 \mu \mathrm{g} / \mathrm{ml}$ ) of MG-262 at $35^{\circ} \mathrm{C}$. After 2 hours, $2 \mu \mathrm{l}$ of $20 \mu \mathrm{M}$ fluorogenic peptide substrate (Calbiochem); SucLeu-Leu-Val-Tyr-AMC (indicator of proteosomal chymotrypsinlike activity) was added and the final volume was adjusted to $200 \mu \mathrm{l}$ with PBS-KCl. After 30 minutes of incubation, the proteasome enzyme activities were measured at $595 \mathrm{~nm}$ via spectrophotometer (Fluoroskan Ascent, Microplate Fluorometer, Thermoscientific). MG-262 untreated cells with fluorogenic peptides were used as controls.

\section{Apoptosis (DNA ladder assay)}

In order to detect the apoptosis effect of MG-262 on test strains, different concentrations of the compound $(25 \mu \mathrm{g} / \mathrm{ml}, 50 \mu \mathrm{g} /$ $\mathrm{ml}, 100 \mu \mathrm{g} / \mathrm{ml}$ and $200 \mu \mathrm{g} / \mathrm{ml}$ ) were tested on $0.5 \times 10^{3}-2.5 \times$ $10^{3} \mathrm{CFU} / \mathrm{ml}$ of the yeast cells. After 3 hours of incubation with MG-262, DNA was extracted according to the protocol described by Suman et al. $[17,18]$. DNA fragmentation was visualized using a 50-10000 bp (base pair) Hi-Lo DNA marker/mass ladder (Bionexus, $A B D$ ) in the $1 \%$ agaroz gel via the gel electrophoresis method at $25 \mathrm{~V}$ for $10 \mathrm{~min}$ and at $50 \mathrm{~V}$ for $30 \mathrm{~min}$. Untreated cells were used as positive control. The results were documented via Gel Logic 2000 gel magnification system (Kodak, USA).

\section{Statistical analysis}

All experiments were performed three times in triplicate. Chisquare test was used to compare filamentous growth, germ tube and DNA ladder assays. Arithmetic mean of absorbance values of oxidative metabolism, biofilm and proteasome activity experiments were calculated. The absorbance values of the negative control wells (containing no cells) were subtracted from the values of the test wells in order to eliminate any background absorbance and compared with the absorbance of the MG-262 untreated cell absorbance results. In the comparison of groups that provide the normal distribution independent samples $T$ test was used while Mann-Whitney $U$ test was used to compare the groups in which normality assumption was not provided. Analyses were performed; using the SPSS for Windows (Version 11.3.8.0) pocket program. Descriptive statistics were shown as mean \pm standart deviation. A probability value of $p$ less than 0.05 was considered statistically significant.

\section{Results}

\section{Antifungal susceptibility tests}

MG-262 exhibited minimum inhibitory activity at $25 \mu \mathrm{g} / \mathrm{ml}$ concentration for C. albicans ATCC 90028 and at $50 \mu \mathrm{g} / \mathrm{ml}$ concentration for C. krusei ATCC 6258 and C. glabrata. MFC of all species were $50 \mu \mathrm{g} / \mathrm{ml}$. MIC of Fluconazole was $1 \mu \mathrm{g} / \mathrm{ml}$ for $C$. albicans whereas MFC of C. krusei and C. glabrata were $\geq 64 \mu \mathrm{g} /$ $\mathrm{ml}$ (interpreted as resistant) and MIC of Amphotericin B was 0.5 $\mu \mathrm{g} / \mathrm{ml}$ for all strains. Negative control did not have any inhibitory effect on any of the Candida species tested.

\section{Corn meal agar and germ tube tests}

The serial dilutions of MG-262 at $25 \mu \mathrm{g} / \mathrm{ml}$ concentration, virulence factors; such as filamentous growth and germ tube formation were still continuing. However at $50 \mu \mathrm{g} / \mathrm{ml}, 100 \mu \mathrm{g} / \mathrm{ml}$ and $200 \mu \mathrm{g} / \mathrm{ml}$ concentrations, they were all inhibited. Figure 1 shows the results of germination and germ tube formation of $C$. albicans at $25 \mu \mathrm{g} / \mathrm{ml}$ and $100 \mu \mathrm{g} / \mathrm{ml}$ concentrations of MG-262.

\section{Oxidative metabolism inhibition}

The control group and $25 \mu \mathrm{g} / \mathrm{ml}$ of MG-262 treated cells developed a pink colour, which is a visual evidence of reduction of AlamarBlue. However, $50 \mu \mathrm{g} / \mathrm{ml}, 100 \mu \mathrm{g} / \mathrm{ml}$ and $200 \mu \mathrm{g} /$ 
$\mathrm{ml}$ treated cells showed no colour change during 24 hour after the addition of the dye. The statistical analysis results of the absorbance values are given both as table (Table 1) and as figure (Figure 2) in order to be more visually descriptive. When values were analyzed statistically, it was observed that MG-262 has a significant effect on the oxidative metabolism of Candida isolates at $50 \mu \mathrm{g} / \mathrm{ml}$ and higher concentrations. At $50 \mu \mathrm{g} / \mathrm{ml}$ concentrations, $\mathrm{p}$ values for $C$. albicans, $C$. krusei ve $C$. glabrata isolates were $0.000,0.046$ and 0.000 , respectively. At $100 \mu \mathrm{g} / \mathrm{ml}$ concentration, $\mathrm{p}$ values for $C$. albicans, $C$. krusei ve $C$. glabrata isolates were $0.000,0.043$ and 0.000 , respectively. Finally at 200 $\mu \mathrm{g} / \mathrm{ml}$ concentrations, $\mathrm{p}$ values for $C$. albicans, $C$. krusei ve $C$. glabrata were found to be $0.003,0.046$ and 0.001 respectively.

\section{Biofilm assays}

The inhibitory effect of MG-262 on cell viability of Candida strains in biofilm condition was observed to be enhanced with increasing concentrations (Figure 3). The ability of MG-262 to inhibit the cells in biofilm was found to be significantly increased at $50 \mu \mathrm{g} / \mathrm{ml}$ and higher concentrations. The most prominent effect was observed at $200 \mu \mathrm{g} / \mathrm{ml}$ concentration. At $50 \mu \mathrm{g} / \mathrm{ml}$ concentrations, $\mathrm{p}$ values for $C$. albicans, $C$. krusei ve $C$. glabrata were $0.000,0.05$ and 0.05 respectively. At $100 \mu \mathrm{g} / \mathrm{ml}$ concentrations, $\mathrm{p}$ values for $C$. albicans, $C$. krusei ve C. glabrata were $0.000,0.046$ and 0.046 respectively. At $200 \mu \mathrm{g} / \mathrm{ml}$ concentrations, $\mathrm{p}$ values for C. albicans, C. krusei ve C. glabrata were $0.000,0.05$ and 0.05 respectively (Table 1 ).

\section{Proteasome activity}

We observed a prominent decrease in the proteasome activity with increasing concentrations of MG-262. The statisticall analysis of absorbance results are given both in (Table 1 and Figure 4).
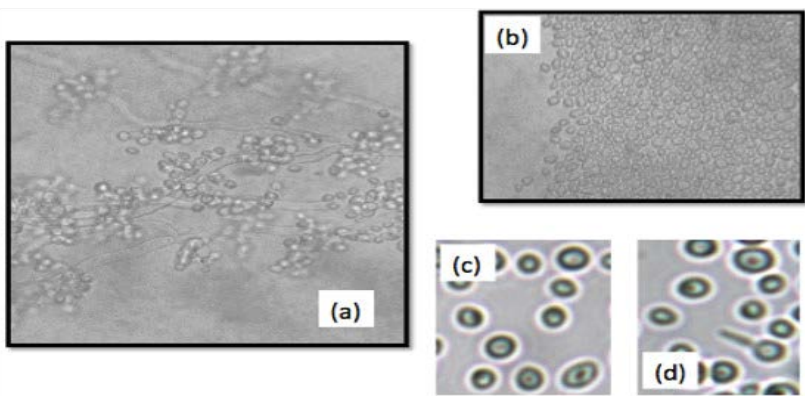

Figure 1 Germination of $C$. albicans on corn meal agar with $25 \mu \mathrm{g} / \mathrm{ml}$ and $100 \mu \mathrm{g} / \mathrm{ml}$ concentrations. Panel (a) represents the hyphal growth after the incubation with $25 \mu \mathrm{g} / \mathrm{ml} \mathrm{MG}-262$. Panel (b) represents the inhibition of hyphal growth after $3 \mathrm{~h}$. contact with $100 \mu \mathrm{g} / \mathrm{ml}$ MG262. Panel (c) represents the inhibition of germ tube after $3 \mathrm{~h}$. contact with $25 \mu \mathrm{g} / \mathrm{ml} \mathrm{MG-262}$. Panel (d) represents the inhibition of germ tube after $3 \mathrm{~h}$. contact with $100 \mu \mathrm{g} / \mathrm{ml} \mathrm{MG-262.}$
Table 1 Statistical analysis results of biofilm reduction, oxidative metabolism and proteasome inhibition experiments.

\begin{tabular}{|c|c|c|c|c|}
\hline & & & t- test & $p$ value \\
\hline \multirow{14}{*}{ Biofilm } & \multirow{4}{*}{ C. albicans } & 200-Unt & $-177,455$ & $0.000 *$ \\
\hline & & $100-$ Unt & $-145,797$ & $0.000 *$ \\
\hline & & 50-Unt & $-52,699$ & $0.000 *$ \\
\hline & & 25-Unt & 0,707 & 0.519 \\
\hline & & & Mann-Whitney U & $p$ value \\
\hline & \multirow{4}{*}{ C. crusei } & 200-Unt & $-1,964$ & 0.05 \\
\hline & & $100-$ Unt & $-1,993$ & $0.46^{*}$ \\
\hline & & 50-Unt & $-1,964$ & 0.05 \\
\hline & & 25-Unt & $-0,886$ & 0.376 \\
\hline & \multirow{4}{*}{ C. glabrata } & 200-Unt & $-1,964$ & 0.05 \\
\hline & & $100-$ Unt & $-1,993$ & $0.46^{*}$ \\
\hline & & 50-Unt & $-1,964$ & 0.05 \\
\hline & & 25-Unt & $-0,655$ & 0.513 \\
\hline & & & t- test & $p$ value \\
\hline \multirow{15}{*}{$\begin{array}{l}\text { Oxidative } \\
\text { Metabolism }\end{array}$} & \multirow{4}{*}{ C. albicans } & 200-Unt & $-18,051$ & $0.003 *$ \\
\hline & & $100-$ Unt & $-41,763$ & $0.000 *$ \\
\hline & & 50-Unt & $-42,079$ & $0.000 *$ \\
\hline & & 25-Unt & 1,782 & 0.198 \\
\hline & & & Mann-Whitney U & $p$ value \\
\hline & \multirow{4}{*}{ C. crusei } & 200-Unt & $-1,993$ & $0.046 *$ \\
\hline & & $100-$ Unt & $-2,023$ & $0.043 *$ \\
\hline & & 50-Unt & $-1,993$ & $0.046 *$ \\
\hline & & 25-Unt & $-0,221$ & 0.825 \\
\hline & & & $\mathrm{t}$ - test & $p$ value \\
\hline & \multirow{4}{*}{ C. glabrata } & 200-Unt & $-22,103$ & $0.001 *$ \\
\hline & & $100-$ Unt & $-114,099$ & $0.000 *$ \\
\hline & & 50-Unt & $-40,588$ & $0.000^{*}$ \\
\hline & & 25-Unt & $-0,131$ & 0.903 \\
\hline & & & T test & $p$ value \\
\hline \multirow{13}{*}{$\begin{array}{l}\text { Proteasome } \\
\text { Inhibition }\end{array}$} & \multirow{4}{*}{ C. albicans } & 200-Unt & $-61,724$ & $0.000 *$ \\
\hline & & $100-$ Unt & $-39,735$ & $0.000 *$ \\
\hline & & 50-Unt & $-23,927$ & $0.000 *$ \\
\hline & & 25-Unt & $-0,979$ & 0.426 \\
\hline & \multirow{4}{*}{ C. crusei } & 200-Unt & $-69,987$ & $0.000 *$ \\
\hline & & $100-$ Unt & $-46,555$ & $0.000 *$ \\
\hline & & 50-Unt & $-24,867$ & $0.000 *$ \\
\hline & & 25-Unt & $-0,436$ & 0.686 \\
\hline & \multirow{5}{*}{ C. glabrata } & & Mann-Whitney U & $p$ value \\
\hline & & 200-Unt & $-1,993$ & $0.046^{*}$ \\
\hline & & 100-Unt & $-1,993$ & $0.046^{*}$ \\
\hline & & 50-Unt & $-1,993$ & $0.046^{*}$ \\
\hline & & 25 -Unt & $-0,664$ & 0.507 \\
\hline
\end{tabular}

When analysed statistically, this effect was significant at $50 \mu \mathrm{g} /$ $\mathrm{ml}$ and higher concentrations. At $50 \mu \mathrm{g} / \mathrm{ml}$ concentrations, $\mathrm{p}$ values for $C$. albicans, $C$. krusei ve $C$. glabrata were $0.000,0.000$ and 0.046 respectively. At $100 \mu \mathrm{g} / \mathrm{ml}$ concentrations, $\mathrm{p}$ values for $C$. albicans, C. krusei ve C. glabrata were $0.000,0.00$ and 0.046 respectively. At $200 \mu \mathrm{g} / \mathrm{ml}$ concentrations, p values for $C$. albicans, C. krusei ve C. glabrata were $0.000,0.000$ and 0.046 respectively. 


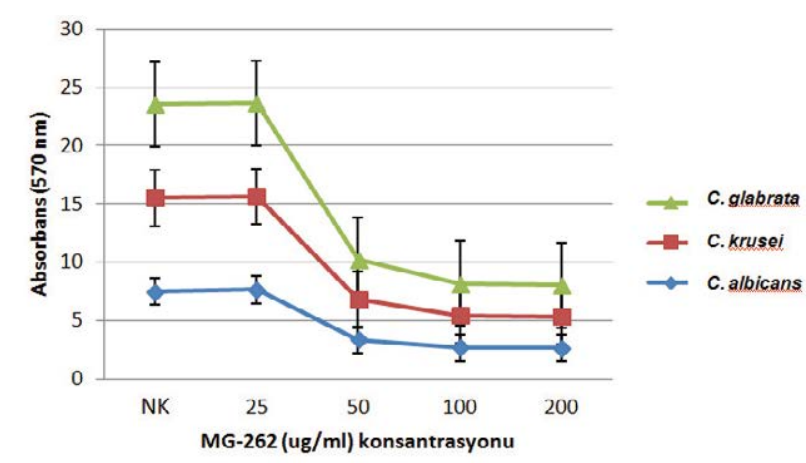

Figure 2 Inhibition of oxidative metabolism with different concentrations of MG-262 (Unt represents Unterated Cells) C. albicans: Candida albicans, C. krusei: Candida krusei, C. glabrata: Candida glabrata.

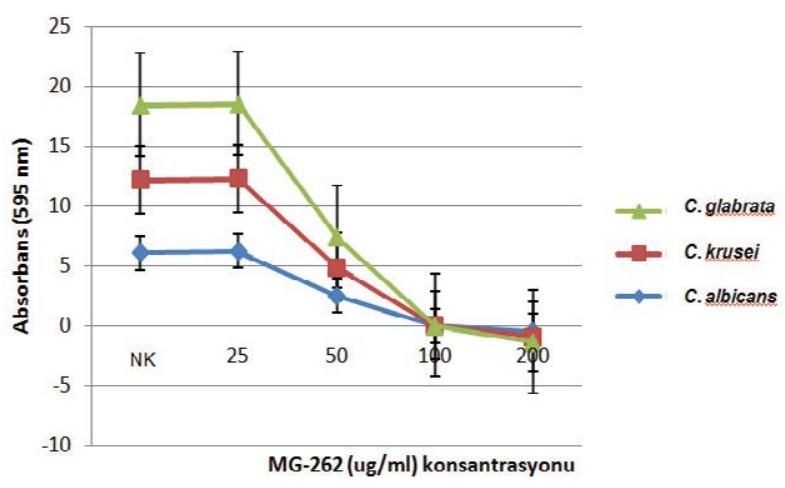

Figure 3 The decrase in biofilm with different concentrations of MG-262 (Unt represents Unterated Cells) C. albicans: Candida albicans, C. krusei: Candida krusei, C. glabrata: Candida glabrata.

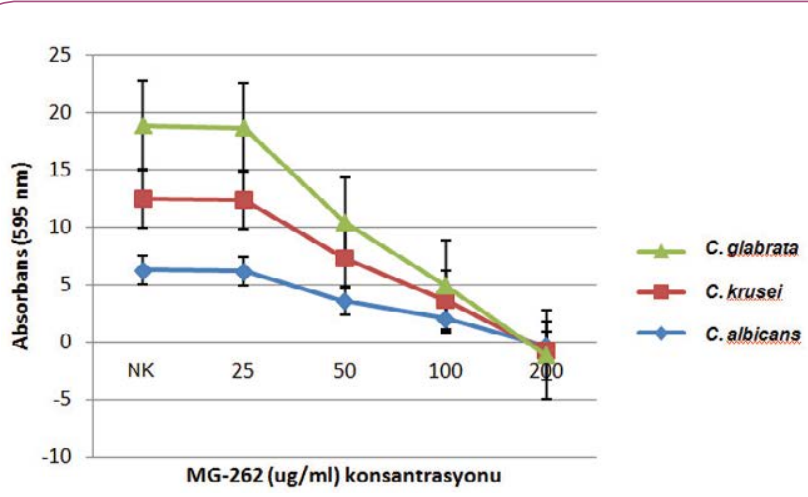

Figure 4 Proteasome activity changes with increasing concentrations of MG-262 (Unt represents Unterated Cells) C. albicans: Candida albicans, C. krusei: Candida krusei, C. glabrata: Candida glabrata.

\section{Apoptosis}

DNA damage was detected only at $200 \mu \mathrm{g} / \mathrm{ml}$ concentration. The DNA ladder image obtained with 200 $\mathrm{mg} / \mathrm{ml} \mathrm{MG-262}$ on gel electrophoresis is given in Figure $\mathbf{5}$.

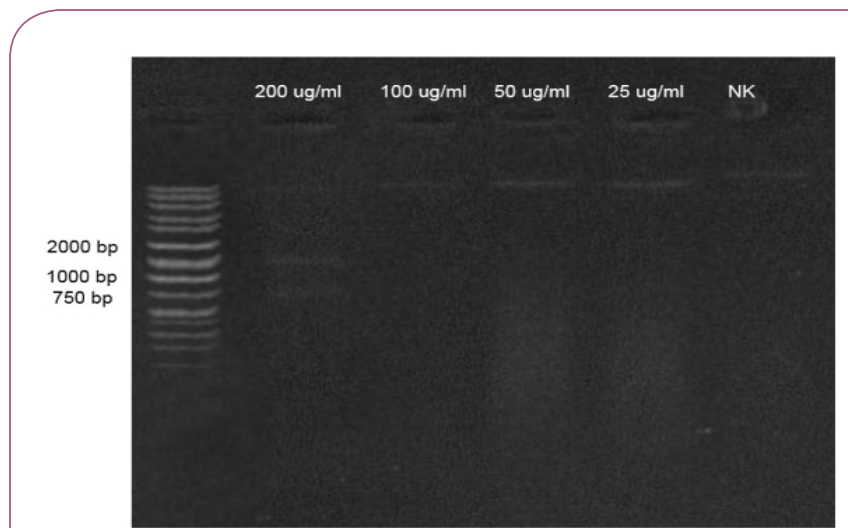

Figure 5 Gel electrophoresis of DNA fragmentation after $3 \mathrm{~h}$ incubation with different concentrations of MG-262. 1400-1550 bp. (base pair) and $750 \mathrm{bp}$. fragments indicates DNA cleavage. Marker: 50-10000 bp HiLo DNA marker/mass ladder (Bionexus, USA)(PC represents positive control).

\section{Discussion}

The aim of our study was to investigate the antifungal activity of MG-262 in for Candida infections. We determined that one of the most potent proteasome inhibitors, MG-262 inhibits virulence factors, and also cause apoptosis by proteasome inhibition and blockage of oxidative metabolism.

The researches on the apoptosis of the yeast give opinion about the apoptotic process of the eukaryotic cells and are promising in competing against unicellular eukaryotic pathogens. New drug molecules are required for life threatening resistant $C$. albicans and non-albicans Candida isolates. Agents performing fungal-programmed cell death can be a model for future novel antifungals [18].

Chymotrypsin-like region of the $20 \mathrm{~S}$ proteasome is a well conserved region both in human and fungus cells. MG-262 is a peptide boronic acid. It inhibits proteasome by binding to chymotrypsin-like region of the $20 \mathrm{~S}$ proteasome in human cells. The properties such as being a more potent agent than other proteasome inhibitors and being resistant to be easily inactivated by oxidation may make MG-262 a good candidate for a novel antifungal drug [10]. The previous in vitro sensitivity analysis have demonstrated that $C$. krusei and $C$. glabrata are more resistant than other Candida strains and MIC values of these two subspecies have shown to be higher than other species [19]. In our study, these two strains which are believed to have a Multi Drug Resistance (MDR) potential were also 2-fold more resistant to MG-262.

Unlike the fungistatic effects of the clinically used local boric acid preparation, MG-262 showed fungicidal activity [6]. The concentration for lethal effect of MG-262 was 2 times higher than for inhibitory effect only for $C$. albicans, for the 2 other strains it was the same concentration. Previous studies have revealed that proteosome inhibitor Bortezomib shows inhibitory effect on both $P$. falciparum and human cells in $\mathrm{nM}$ concentrations $[7,20]$. In our study MIC and MFC of the MG-262 were in $\mu \mathrm{M}$ concentration 
range and far above nM levels. We suggest that this can be due to the mechanical strength of the cell wall which consists of $\beta 1,3-$ glucan and chitin [21]. On the other hand, when compared with the other proteasome inhibitors, it showed efficacy at much lower concentration on the yeast probably secondary to being a more potent agent [22].

In addition to the effective concentration, the effects on virulence factors are also of great importance when an agent is being investigated as a potential novel antimicrobial. In our study, the effects of MG-262 on germ tube, hyphe, pseudohypha and cell viability in biofilm condition were examined. Candida infections generally originate from implants such as prosthetic valves, endotracheal tubes and joint prostheses. The major virulence factors are biofilm formation and adhesion to the biomaterial surface [23]. The hyphal growth and germ tube development capabilities of the fungus cells are also important in the formation of cell damage and deeply located infections [24]. MG-262 inhibited hyphal growth, germ tube and pseudohypha formation at $50 \mu \mathrm{g} / \mathrm{ml}$ and higher concentrations. The effects on cell viability in biofilm were more prominent with increasing MG262 concentrations (Figure 3). The antimicrobial resistance of the biofilm-producing microorganisms can be up to 1000 -fold greater than planctonic cells [25]. Therefore, the inhibition at higher concentration and the most efficacy at $200 \mu \mathrm{g} / \mathrm{ml}$ concentration can not to be regarded as a surprising finding.

Proteaosome inhibitors cause apoptosis in almost all cells at high concentrations [10]. Our study was in line with this literature, indicating that MG-262 provided a significant proteasome inhibition only at $50 \mathrm{\mu g} / \mathrm{ml}$ and higher concentration.

The breakdown of the oxidative metabolism in cells and associated oxidative stress are the most substantial signals portending the death due to apoptosis [26]. In the oxidationreduction experiments of our study, the color had changed to pink both in control strains and $25 \mu \mathrm{g} / \mathrm{ml} \mathrm{MG}-262$ treated strains in about 1 hour whereas the blue color had not changed in the following 24 hours beginning from $50 \mu \mathrm{g} / \mathrm{ml}$ concentration. These results showed that oxidative metabolism was blocked in increasing concentrations from $50 \mu \mathrm{g} / \mathrm{ml}$. It has been reported that the effect of some protease inhibitors is reversible [26].

\section{References}

1 Wisplinghoff $\mathrm{H}$, Bischoff T, Tallent SM, Seifert $\mathrm{H}$, Wenzel RP et al. (2004) Nosocomial bloodstream infections in US hospitals: analysis of 24,179 cases from a prospective nationwide surveillance study. Clin Infect Dis 39: 309-317.

2 Martins N, Ferreira IC, Barros L, Silva S, Henriques M (2014) Candidiasis: predisposing factors, prevention, diagnosis and alternative treatment.Mycopathologia 177: 223-240.

3 Williams DW, Kuriyama T, Silva S, Malic S, Lewis MA (2011) Candida biofilms and oral candidosis: treatment and prevention. Periodontol 55: 250-265.

4 Pappas PG, Kauffman CA, Andes DR, Clancy CJ, Marr KA, et al. (2016) Clinical Practice Guideline for the Management of Candidiasis: 2016
However, in our study, the effect of MG-262 lasts for 24 hours, suggesting that the effect of MG-262 on tested Candida species is not reversible.

The specific finding of apoptosis is fragmentation of the cellular DNA from the regions between nucleosomes leading to formation of about 180 to 200 bp or multiples sized DNA pieces [27]. DNA ladder appearance is the final stage and precise finding of apoptosis. However DNA fragments in yeast are composed of much larger base pairs. DNA fragments as large as 800 bp were demonstrated in Saccharomyces pompe in the previous studies [28]. In our study, the DNA fragments were approximately $750 \mathrm{bp}$ and 1450-1500 bp in size when compared to DNA HiLo marker. Although statistically significant proteasome inhibition was detected at 50, 100 and $200 \mu \mathrm{g} / \mathrm{ml}$ concentrations, DNA ladder image could only be detected at $200 \mu \mathrm{g} / \mathrm{ml}$ concentration. This might be because of the limitation of the DNA ladder assay since it may causes loss of DNA fragments during sample processing $[17,27]$.

The current study demonstrates that MG-262 caused antifungal activity on Candida species via apoptosis. The possible mechanism of action was inhibition of chymotrypsin-like activity. Although the data about the dose related toxic effects and antimicrobial resistance is currently missing, this novel therapeutic approach deserves further researches since it has the potential to remediate Candida infections resistant to existing treatment modalities. We conclude that this boric acid anolog not only inhibits virulence factors, but also cause apoptosis by proteasome inhibition and blockage of oxidative metabolism on several Candida spp. However our work was a pre-study. Many different types of new proteasome inhibitors on human cells have been described, including grape, soy polyphenols and Bortezomib, a drug approved by FDA and these molecules are still untouched for yeast species. Determination of mechanisms of actions of different proteasome inhibitors and boric acid anologs may open the way to drug discovery for Candida infections.

\section{Funding}

This work was supported by the Coordinatorship of Scientific Research Projects of Ankara University (10B3330025).

Update by the Infectious Diseases Society of America. Clin Infect Dis 62: e1-50.

5 das Neves J, Pinto E, Teixeira B, Dias G, Rocha P, et al. (2008) Local Treatment Of Vulvovaginal Candidosis:general and practical considerations. Drugs 68:1787-1802.

6 Seta FD, Schmidt M, Essmann BV, Larsen B (2009) Antifungal mechanisms supporting boric acid therapy of Candida vaginitis. J Antimicrob Chemother 63: 325-336.

7 Reynolds JM, El Bissati K, Brandenburg J, Günzl A, Mamoun CB (2007) Antimalarial activity of the anticancer and proteasome inhibitor bortezomib and its analog ZL3B. BMC Clin Pharmacol 7: 13.

8 Wojcik C (2002) Regulation of apoptosis by the ubiquitin and proteasome pathway. J Cell Mol Med d 6: 25-48. 
9 Wojcik C (2002) Regulation of apoptosis by the ubiquitin and proteasome pathway. J Cell Mol Med 6: 25-48.

10 Kisselev AF, van der Linden WA, Overkleeft HS (2012) Proteasome inhibitors: an expanding army attacking a unique target. Chem Biol 19: 99-115.

11 Clinical and Laboratory Standards Institute (CLSI) (2008) Reference method for broth dilution antifungal susceptibility testing of yeasts: approved standard. $3^{\text {rd }}$ edn. CLSI document M27-A3. Wayne, PA: Clinical and Laboratory Standards Institute 22: 156.

12 Clinical and Laboratory Standards Institute (CLSI) (2012) Reference method for broth dilution antifungal susceptibility testing of yeasts, 4th informational supplement. CLSI document M27-S4.

13 Oro D, Heissler A, Rossi EM, Scapin D, Malheiros PS, et al. (2015) Antifungal activity of natural compounds against Candida species isolated from HIV-positive patients. Asian Pac J Trop Biomed 5: 781-784.

14 Mahmoudi Rad M, Zafarghandi S, Abbasabadi B, Tavallaee M (2011) The epidemiology of Candida species associated with vulvovaginal candidiasis in an Iranian patient population. Eur J Obstet Gynecol Reprod Biol 155: 199-203.

15 Rampersad SN (2012) Multiple Applications of Alamar Blue as an Indicator of Metabolic Function and Cellular Health in Cell Viability Bioassays. Sensors (Basel, Switzerland) 12: 12347-12360.

16 Evensen NA, Braun PC (2009) The effects of tea polyphenols on Candida albicans: inhibition of biofilm formation and proteasome inactivation. Can J Microbiol 55: 1033-1039.

17 Suman S, Pandey A, Chandna S (2012) An improved non-enzymatic "DNA ladder assay" for more sensitive and early detection of apoptosis. Cytotechnology 64: 9-14.
18 Madeo F, Herker E, Wissing S, Jungwirth H, Eisenberg T, et al. (2004) Apoptosis in yeast. Curr Opin Microbiol 7: 655-660.

19 Pfaller MA, Diekema DJ, Sheehan DJ (2006) Interpretive breakpoints for fluconazole and Candida revisited: a blueprint for the future of antifungal susceptibility testing. Clin Microbiol Rev 19: 435-447

20 Shabaneh TB, Downey SL, Goddard AL (2013) Molecular basis of differential sensitivity of myeloma cells to clinically relevant bolus treatment with bortezomib. PLoS One 8: e56132.

21 Klis FM, Mol P, Hellingwerf K, Brul S (2002) Dynamics of cell wall structure in Saccharomyces cerevisiae. FEMS Microbiology Reviews 26: $239-256$.

22 Evensen NA, Braun PC (2009) The effects of tea polyphenols on Candida albicans:inhibition of biofilm formation and proteasome inactivation. Can J Microbiol 55: 1033-1039.

23 Seneviratne CJ, Jin L, Samaranayake LP (2008) Biofilm lifestyle of Candida: a mini review. Oral Dis 14: 582-590.

24 Calderone RA, Fonzi A (2001) Virulence factors of Candida albicans. Trends in Microbiology 9: 327-335.

25 Mah TF, O'Toole GA (2001) Mechanisms of biofilm resistance to antimicrobial agents. Trends Microbiol 9: 34-39.

26 Kannan K, Jain SK (2007) Oxidative stress and apoptosis. Pathophysiology 7: 153-163.

27 Rahbar SY, Saeidi N, Zununi VS, Barzegari A, Barar J (2015) An update to DNA ladder assay for apoptosis detection. Bioimpacts 5: 25-28.

28 Zörnig IK, Baum M, Hajibagheri B, James N, Chittenden C, et al. (1997) Human Bak induces cell death in Schizosaccharomyces pombe with morphological changes similar to those with apoptosis in mammalian cells. Molecular and Cellular Biology 17: 2468-2474. 